\title{
A água sabe a lixívia
}

A água de abastecimento público, é, por imposição legal, de qualidade própria para consumo humano, isto é, potável. Algures ter-nos-ão dito que a água é insípida, incolor e inodora; são as chamadas características organolépticas, isto é aquelas que são detectadas pelos nossos sentidos. Sabemos entretanto que não só a água, $\mathrm{H}_{2} \mathrm{O}$, não é estritamente incolor do ponto de vista espectroscópico, como também encontramos águas com diferentes sabores e até odores, que Ihe são conferidos por substâncias nela dissolvidas. Para além destas características físico-químicas, que devem obedecer a limites estabelecidos em diplomas próprios (Lei da Qualidade da Água, DL 236/98 e 243/2001), a água deve ser bacteriologicamente pura, isto é, deve estar isenta de microorganismos patológicos. Durante décadas foi esta última a principal preocupação relativamente à qualidade da água para beber e uma das formas tradicionais de o conseguir, a nível doméstico, era a fervura. Outras formas de conseguir essa desinfecção usadas em grande escala pelas instituições de distribuição, são a cloragem e, mais recentemente, a ozonização.

Na cloragem, a acção anti-séptica do cloro deve-se à hidrólise do cloro molecular, $\mathrm{Cl}_{2}$, ou à acidificação de um hipoclorito (ex: hipoclorito de sódio, $\mathrm{NaOCl}$ ) dando lugar à formação de ácido hipocloroso, $\mathrm{HOCl}$, que é um agente bactericida. A lixívia de uso doméstico é uma solução aquosa de hipoclorito de sódio ou de potássio.

Quando $\mathrm{Cl}_{2}$ é adicionado à água, ocorre a reacção de hidrólise
$\mathrm{Cl}_{2}+\mathrm{H}_{2} \mathrm{O} \rightleftarrows \mathrm{HOCl}+\mathrm{H}^{+}+\mathrm{Cl}^{-}$

No caso do hipoclorito de sódio, $\mathrm{NaOCl}$, em solução aquosa, este dissocia-se

$\mathrm{NaOCl} \rightleftarrows \mathrm{OCl}^{-}+\mathrm{Na}^{+}$

$\mathrm{OCl}^{-}+\mathrm{H}^{+} \rightleftarrows \mathrm{HOCl} \quad\left(\mathrm{pK}_{\mathrm{a}}=7,5 \mathrm{a} 25^{\circ} \mathrm{C}\right)$

$\mathrm{O}$ facto de a espécie química $\mathrm{HOCl}$ ser um melhor desinfectante que a sua base conjugada $\mathrm{OCl}^{-}$(de mais difícil penetração nas bactérias devido à carga), torna o valor de pH um parâmetro importante na eficácia da cloragem.

Caso amónia, $\mathrm{NH}_{3}(\mathrm{aq})$, esteja presente na água, o ácido hipocloroso pode reagir com o amoníaco produzindo cloraminas,

$$
\begin{aligned}
& \mathrm{NH}_{3}+\mathrm{HOCl} \rightleftarrows \mathrm{H}_{2} \mathrm{O}+\mathrm{NH}_{2} \mathrm{Cl} \\
& \text { (monocloramina) } \\
& \mathrm{NH}_{2} \mathrm{Cl}+\mathrm{HOCl} \rightleftarrows \mathrm{H}_{2} \mathrm{O}+\mathrm{NHCl}_{2} \\
& \text { (dicloramina) } \\
& \mathrm{NHCl}_{2}+\mathrm{HOCl} \rightleftarrows \mathrm{H}_{2} \mathrm{O}+\mathrm{NCl}_{3} \\
& \text { (tricloramina) }
\end{aligned}
$$

As cloraminas decompõem-se mesmo na ausência de outro material reactivo.

$2 \mathrm{NHCl}_{2}+\mathrm{H}_{2} \mathrm{O} \rightleftarrows \mathrm{N}_{2}+\mathrm{HOCl}+3 \mathrm{H}^{+}+3 \mathrm{Cl}^{-}$

Esta reacção ocorre até que todo o azoto amoniacal é oxidado a azoto molecular. A partir deste ponto, a adição de mais "cloro", seja ele efectivamente cloro, $\mathrm{Cl}_{2}$, ou um composto clorado, vai dar origem a cloro livre residual.

Apesar de não ser uma prática corrente em Portugal, as próprias cloraminas podem ser utilizadas como agentes desinfectantes. As espécies $\mathrm{HOCl}$ e $\mathrm{OCl}^{-}$são mais vantajosas por requerem tempo de contacto mais curto e uma dosagem menor, para o mesmo nível de desinfecção. As cloraminas apresentam a seu favor o facto de produzirem um residual mais estável que o do cloro, garantindo uma acção de desinfecção mais prolongada ao longo do tempo e das condutas da água. Por esta razão são utilizadas frequentemente nas desinfecções secundárias, onde o maior interesse se centra no seu poder residual e não tanto na potência da desinfecção.

O cloro é um desinfectante bastante forte e encontra utilização não só na desinfecção da água mas também na destruição por oxidação de compostos causadores de cheiros, sabores e cores indesejáveis, em outros sectores de actividade.

É preocupante que, na desinfecção de águas de efluentes, estejam a ser utilizadas cada vez maiores quantidades de "cloro" e que os níveis de cloro residual sejam baixos. Tal significa que, as medidas de prevenção não estarão a ser eficazes, com a carga poluente das águas a aumentar. A perda de concentração de cloro residual processa-se por vaporização natural, ou por reacções do cloro com outras espécies químicas presentes. Estas reacções, sobretudo com compostos orgânicos, dão origem a compostos organoclorados (ex: clorofórmio, clorobenzenos e clorofenóis), subprodutos conhecidos pelo nome genérico Desinfection By-Products, DBPs, alegadamente cancerígenos. A eliminação destes compostos tóxicos, consegue-se à custa da permanência em locais de retenção, por tempo mais ou 
menos prolongado, acompanhada de oxigenação por arejamento.

A água da torneira, se for guardada num recipiente, de preferência de vidro (evitar metal que corre o perigo de ser oxidado com passagem dos iões respectivos para a água), vai perdendo cloro residual e, em uma ou duas horas, terá perdido o desagradável sabor a "cloro".

Outro processo de desinfecção da água de beber, é a ozonização, ou oxidação por ozono, $\mathrm{O}_{3}$. O ozono é o oxidante mais potente que se pode produzir industrialmente de forma económica, sendo o mais usado na Europa e nos Estados Unidos da América. É muito reactivo e decompõe-se com facilidade em oxigénio atómico, $\mathrm{O}$, e molecular, $\mathrm{O}_{2}$. O primeiro, O, é responsável por grande actividade química, o segundo tem a vantagem adicional de fornecer oxigénio, $\mathrm{O}_{2}$, recriando condições aeróbias. A decomposição é rápida, dependendo o tempo da carga poluente existente, do $\mathrm{pH}$ e da temperatura. Tem forte acção sobre as bactérias, sendo considerado o agente microbicida mais rápido e eficaz que se conhece. A sua acção possui um largo espectro na eliminação de bactérias, vírus e fungos. Destrói grande número de moléculas orgânicas, decompondo as macromoléculas em fracções mais simples. 0 ozono reage mais eficazmente com compostos orgânicos insaturados, mais nas duplas ligações $\mathrm{C}=\mathrm{C}$ do que nas $\mathrm{C}=\mathrm{N}$.

Concentrações de 0,1 a 0,5 mg/L, durante 5 segundos, eliminam as bactérias e a maior parte dos esporos e larvas de insectos. Além da desinfecção e da oxigenação da água, tem-se observado o seu poder de flocular matéria orgânica coloidal. A vasta aplicação do processo no ataque aos microrganismos, tem levado a verificar a forte acção desodorizante e, como consequência, o seu aproveitamento para tratamento de certos odores de origem industrial.

O ozono desaparece muito rapidamente e não comunica sabor ou cheiro à água. No entanto, a aplicação do ozono não é isenta de perigos e carece de cautela. A água ozonizada não deve ser consumida directamente, devendo ser alvo de tratamento que garanta a eliminação de ozono residual, por desarejamento, em cascata ou outra forma de contacto intenso ou prolongado com o ar. Existe também evidência da oxidação de espécies químicas minerais, cloretos $\mathrm{Cl}^{-}$, a cloratos, $\mathrm{ClO}_{3}^{-}$; brometos, $\mathrm{Br}^{-}$, a bromatos, $\mathrm{BrO}_{3}{ }^{-}$, etc., de toxicidade a não desprezar.

Embora hajam utilizações menos exigentes do que a água potável (ex: rega), esta não corresponde de todo ao grau de pureza mais exigente; havendo utilizações que requerem maior purificação. Aplicações clínicas, ou usos laboratoriais são exemplos conhecidos, em que se exige água destilada, ou desionizada. O objectivo é a purificação, isto é a separação da água dos contaminantes que a acompanham. Essa purificação é efectuada normalmente por destilação, ou por desionização ou desmineralização.
Na destilação destila-se, isto é aquecese e recolhe-se o vapor que se condensa. No balão de destilação ficaram resíduos não voláteis, mas como o processo não é 100\% eficiente a água obtida por destilação terá ainda níveis vestigiários de contaminantes que acompanharam o vapor. Caso seja necessário, pode-se repetir a destilação uma ou duas vezes e obtém-se água bidestilada, ou tridestilada, de maior pureza. A destilação liberta a água de contaminantes orgânicos e inorgânicos não voláteis. Em muitos locais, em alternativa à água destilada, usa-se água desionizada, a que, como o nome diz, foram removidos os iões das substâncias nela dissolvidas, por interacção com resinas troca-iónica, troca catiónica para os catiões e troca aniónica para os aniões. Pense-se no exemplo de uma água com uma substância mineral, iónica, dissolvida, ex: o sal cloreto de sódio, $\mathrm{NaCl}$, e outra orgânica, molecular, ex: açúcar, $\mathrm{C}_{6} \mathrm{H}_{12} \mathrm{O}_{6}$. A sua destilação remover-lhe-á açúcar e cloreto de sódio, mas a sua desionização ou desmineralização só será eficaz sobre o cloreto de sódio. Por isso, antes de submeter água a desionização ela deverá ser previamente alvo de uma destilação que Ihe remove as substâncias orgânicas; só depois deverá ser introduzida nas colunas de resinas, tendo também já uma menor carga de compostos minerais. Caso se pretenda uma água destilada ou desionizada mais isenta de matéria orgânica, já em pequena quantidade, pode submeter-se a água à acção de radiação ultra-violeta.

\section{Química preenche mais vagas na $1 .^{\mathrm{a}}$ fase}

Na 1. ${ }^{a}$ fase de acesso ao ensino superior foram preenchidas 1065 das 1686 vagas disponíveis em cursos da área de Química (63,2%). Estes números indicam uma ligeira recuperação em relação ao ano anterior, quando foram preenchidas 1055 das 1746 vagas postas a concurso $(60,4 \%)$. Os cursos com maior número de candidatos são os cursos de Bioquímica, que preencheram $99 \%$ das vagas disponíveis, deixando apenas 6 vagas para a 2. ${ }^{\text {a }}$ fase. $\mathrm{Na}$ situação oposta encontram-se os cursos de Física e Química (Ensino), com apenas $18 \%$ das vagas preenchi- das num total de 80. Os cursos de Engenharia Química registam uma procura moderada, com $46 \%$ das vagas preenchidas, deixando 367 vagas disponíveis para 2. ${ }^{a}$ fase. No entanto, as 70 vagas da Faculdade de Engenharia da Universidade do Porto foram totalmente preenchidas, sendo a nota do último aluno colocado 140,0. Os cursos de Química (incluindo Química, Química Industrial, Química Aplicada e Química Tecnológica) tiveram uma percentagem de ocupação próxima da média da área (63\%). Num total de 490 vagas disponíveis, so-

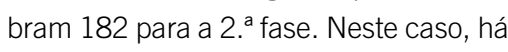
3 instituições com preenchimento total das vagas: Universidade do Porto - Fa- culdade de Ciências (Química), Universidade Nova de Lisboa - Faculdade de Ciências e Tecnologia (Química Aplicada), e Universidade do Minho (Química Aplicada, ramo de Materiais Plásticos). Esta análise por sectores revela uma inversão na taxa de ocupação dos cursos de Química e de Engenharia Química entre 2004 e 2005. Em 2004, as taxas de ocupação foram de $59 \%$ nos cursos de Engenharia Química e de 42\% nos cursos de Química. Em números absolutos, relativamente a 2004, as licenciaturas em Química ganharam 67 alunos enquanto as licenciaturas em Engenharia Química perderam 100 alunos.

Paulo Ribeiro Claro 